E-ISSN : 2549-6581

DOI: 10.21776/ub.JOIM.2020.004.01.4

Artikel Hasil Penelitian

Diterima : 2 Juli 2018

Direview : 3 Februari 2020

Dimuat : April - Juli 2020
OPEN ACCESS

Journal of Issues in Midwifer

\title{
Hubungan Pola Bermain Gadget dengan Kemampuan Kognitif dan Berpikir Kreatif pada Usia Prasekolah (5-6 Tahun) di TK-Aisyiyah Bustanul Athfal 33 Cita Insani Malang
}

\author{
Rifdah Maulia', Miftahul Jannah², Dewi Ariani ${ }^{3}$ \\ ${ }^{1}$ Mahasiswa Program Studi S1 Kebidanan, Fakultas Kedokteran, Universitas Brawijaya Malang \\ Email : rifdahmaulia@gmail.com Tlp :+6285891836168 \\ ${ }^{2}$ Dosen Program Studi S1 Kebidanan, Fakultas Kedokteran, Universitas Brawijaya Malang \\ ${ }^{3}$ Dosen Program Studi ProfesiBidan, Fakultas Kedokteran, Universitas Brawijaya Malang
}

\begin{abstract}
In English, a gadget is a small electronic device with various special functions. In Indonesia, gadget do not only belong to adults, but also to early childhood (2-6 years old). Using gadgets at preschool age have a negative and positive impact, depending on the pattern of using gadgets such as duration, frequency, type of the apps, type of the games and parent's control while children playing gadget. If the pattern of using gadget is appropriate with children's age, it will have positive impacts such as improving cognitive abilities and creative thinking. This study aims to determine relationship between the pattern of playing gadgets and cognitive abilities and creative thinking in preschoolers (5-6 years old) at TK-Aisyiyah Bustanul Athfal 33 Cita Insani Malang. The research used Cross-Sectional. The sample of this study is preschool students at TK-Aisyiyah Bustanul Athfal 33 Cita Insani Malang $(n=43)$ which were determined by purposive sampling. The result of nonparametric statistical Rank Spearman shows that there is no relationship between the pattern of using gadgets with cognitive abilities, while there is a relationship between the pattern of using gad gets with creative thinking abilities in preschool children (aged 5-6 years old) at TKAisyiyah Bustanul Athfal 33, Cita Insani Malang.
\end{abstract}

Keywords: gadget, cognitive, creative thinking, creativity, early childhood, preschool children.

\section{ABSTRAK}

Gadget merupakan istilah yang berasal dari bahasa inggris yang artinya sebuah alat elektronik dengan berbagai macam fungsi khusus. Selain orang dewasa, Gadget juga beredar di kalangan anak usia prasekolah (2-6 tahun) khususnya di negara Indonesia. Penggunaan gadget pada usia prasekolah dapat berdampak negatif dan positif, tergantung dari pola penggunaan gadget pada anak meliputi durasi, frekuensi, jenis aplikasi, jenis permainan dan ada atau tidaknya dampingan orangtua pada saat anak bermain gadget. Apabila pola bermain gadget anak baik dan sesuai dengan usianya, maka akan berdampak positif seperti peningkatan kemampuan kognitif dan berpikir 
kreatif. Penelitian ini bertujuan untuk mengetahui hubungan pola bermain gadget dengan kemampuan kognitif dan berpikir kreatif pada anak usia prasekolah (5-6 tahun) di TK-Aisyiyah Bustanul Athfal 33 Cita Insani Malang. Desain penelitian yang digunakan adalah Cross Sectional. Sampel dari penelitian ini adalah siswa TK-Aisyiyah Bustanul Athfal 33 Cita Insani Malang $(n=43)$ yang ditentukan dengan metode purposive sampling. Hasil uji statistik nonparametrik Rank Spearman dengan menggunakan SPSS 16 for Windows dapat disimpulkan bahwa tidak terdapat hubungan pola bermain gadget dengan kemampuan kognitif dan terdapat hubungan antara pola bermain gadget dengan kemampuan berpikir kreatif pada anak usia prasekolah (usia 5-6 tahun) di TK-Aisyiyah Bustanul Athfal 33 Cita Insani Malang.

Kata kunci: gadget, kognitif, berpikir kreatif, kreativitas, anak usia dini, anak prasekolah.

*Korespondensi :Rifdah Maulia.Surel :rifdahmaulia@gmail.com

\section{PENDAHULUAN}

Teknologi berperan penting dalam kehidupan manusia seharihari. Salah satu bentuk teknologi yang sangat populer dewasa ini adalah gadget. Gadgetmerupakan sebuah istilah yang berasal dari bahasa inggris yang artinya sebuah alat elektronik dengan berbagai macam fungsi khusus. Beberapa jenis gadgetyang telah banyak digunakan diantaranya komputer, laptop, smartphone dan tablet.Selain orang dewasa, Gadget juga beredar di kalangan anak usia prasekolah (2-6 tahun) khususnya di negara Indonesia,hal ini terbukti dengan hasil survei yang dilakukan Wijanarko dkkbahwa di tahun 2012 anak usia dini hanya $27 \%$ yang menggunakan gadget, dan meningkat hingga $73 \%$ pada tahun 2014. Didapatkan pula bahwa anakanak yang menggunakan gadgetpaling sering menonton film, program televisi, video klip, mendengarkan lagu, bermain game, maupun aplikasi. ${ }^{1}$

Penggunaan gadget yang terus-menerusakan berdampak buruk bagi pola perilaku anak dalam kesehariannya, salah satunya adalah mereka akan sangat ketergantungan dan menjadikan hal tersebut sebagai kegiatan rutin yang harus dilakukan oleh anak dalam kehidupannya sehari-hari. Selain itu, anak lebih sering bermain gadget dibandingkan berinteraksi, bersosialisasi dengan lingkungannya dan belajar, Hal ini sangat mengkhawatirkan, karna pada masa ini, mereka masih tidak stabil, tingginya rasa keingintahuan dan sifat konsumtif anak akan semakin meningkat. Untuk itu, orang tau harus lebih memperhatikan lagi penggunaan gadget pada anakanak.

Dampak positif bermain gadget berhubungan dengan proses perkembangan kognitif, pengembangan representasi simbolis, pengembangan perhatian, peluang dan pemahaman esensi, klasifikasi yang lebih cepat dan dengan jelas, pengambilan keputusan, analisis, pemahaman hubungan sebab-akibat, pengembangan memori, mendorong 
kreativitas, mendorong rasa ingin tahu, mengembangkan imajinasi, proses pemecahan masalah dan meningkatkan motivasi.

Permainan elektronik pada gadget dapat mengembangkan sensibilitas anak-anak. Hal ini dipercaya bahwa teknologi modern memberi kesempatan pada anak untuk mengembangkan inisiatif kemandirian dan berimajinasi, yang menjadi penguat kreativitas anak yang kemudian dapat merangsang dan memungkinkan anak untuk menemukan aspek yang berbeda dari pengalaman, mempercapat pematangan intelektual mereka dan mendorong mereka untuk mengembangkan potensi kreatif. $^{2}$ Pentingnya berpikir kreatif dikembangkan dalam pembelajaran di kelas telah dilaporkan oleh Supardi (2015) yakni berpikir kreatif berperan positif dalam meningkatkan hasil belajar kognitif siswa. $^{3}$

Dari data-data tersebut, peneliti tertarik untuk menggali lebih lanjut tentang hubungan pola bermain gadget dengan kemampuan kognitif dan berpikir kreatif pada anak prasekolah usia 5 tahun sampai 6 tahun. Dengan lebih banyak penelitian, diharapkan akan menghasilkan bukti empiris yang akan memberikan manfaat bagi masyarakat terutama pada anak prasekolah yang menggunakan gadget sebagai media belajar dan bermain. Gadget yang digunakan dalam penelitian ini lebih spesifik yaitu anak yang menggunakan komputer, laptop, smartphone dan tablet sehingga penelitian ini lebih terfokus.

\section{METODE PENELITIAN}

Penelitian ini menggunakan desain penelitian cross sectional. Populasi pada penelitian ini adalah anak usia (5-6 tahun) di TK-Aisyiyah Bustanul Athfal. Teknik pengambilan sampel dalam penelitian ini menggunakan Purposive Sampling. Dengan kriteria inklusi : orang tua yang memiliki anak usia 5-6 tahun, bisa membaca, mendengar dan berbahasa indonesia, anak prasekolah usia 5-6 tahun, Anak dalam keadaan sehat. dan didapatkan jumlah sampel sebanyak 43 anak.

Pengumpulan data pada penelitian ini menggunakan kuesioner orangtua tentang pola bermain gadget anak dengan hasil ukur sesuai = bila skor $\geq 14$, cukup sesuai $=$ bila skor $10-13$ dan kurang sesuai $=$ bila skor $\leq 9$. Untuk variabel kemampuan kognitif anak dapat diukur menggunakan lembar observasi kemampuan kognitif usia 5-6 tahun dari Depsiknas (2003) dengan hasil ukur kognitif baik = bila skor $75 \%-100 \%$ terjawab benar, kognitif cukup = bila skor 56\%-75\% terjawab benar dan kognitif kurang = bila $<56$ terjawab benar. Sedangkanpengukuran berpikir kreatif pada anak dapat diukur menggunakan Torrance Test of Creative Thinking dengan hasil ukur kreativitas tingg = bila $\geq 75 \%$ terjwab benar, kreativitas sedang= bila $51 \%$ $74 \%$ terjawab benar dan kreativitas rendah $=$ bila $\leq 50 \%$ terjawab benar.

Analisisdalam penelitian ini menggunakan uji statistika nonparametric yaitu Rank Spearman. Uji ini memiliki $\alpha=0,05$. 


\section{HASIL PENELITIAN DAN ANALISIS DATA}

\section{Karakteristik Responden}

Tabel 1 Distribusi Frekuensi Responden Berdasarkan Jenis Kelamin

\begin{tabular}{ccc}
\hline Jenis Kelamin & Frekuensi & Presentase \\
\hline Laki-laki & 22 & $51 \%$ \\
\hline Perempuan & 21 & $49 \%$ \\
\hline Total & 43 & $100 \%$ \\
\hline
\end{tabular}

Sesuai dengan tabel diatas, dapat disimpulkan bahwa dari 43 responden didapatkan 22 responden (51\%) berjenis kelamin laki-laki dan 21 responden (49\%) berjenis kelamin perempuan.

Tabel 2 Distribusi Frekuensi Responden Berdasarkan Usia

\begin{tabular}{ccc}
\hline Usia & Frekuensi & Presentase \\
\hline 5 Tahun & 14 & $32,5 \%$ \\
\hline 6 Tahun & 29 & $67,5 \%$ \\
\hline Total & 43 & $100 \%$ \\
\hline
\end{tabular}

Sesuai dengan tabel diatas,dapat disimpulkan bahwa dari 43 responden didapatkan sampel terbanyak adalah pada usia 6 tahun, yaitu 29 responden $(67,5 \%)$ dan sampel yang paling sedikit adalah responden pada usia 5 tahun sebanyak 14 responden (32,5\%).

\section{Analisis Univariat}

Tabel 3 Distribusi Frekuensi Responden Berdasarkan Pola Bermain Gadget Pada Anak Usia Prasekolah

\begin{tabular}{ccc}
\hline Pola Bermain Gadget & Frekuensi & Presentasi \\
\hline Sesuai $($ Skor $\geq 14)$ & 27 & $62,8 \%$ \\
\hline Cukup Sesuai $($ Skor $10-13)$ & 13 & $30,2 \%$ \\
\hline Kurang Sesuai $($ Skor $\leq 9)$ & 3 & $7 \%$ \\
\hline Total & 43 & $100 \%$ \\
\hline
\end{tabular}

Berdasarkan pada tabel diatas dapat disimpulkan bahwa anak usia Preschool (5-6 Tahun) di TK-Aisyiyah Bustanul Athfal 33 Cita Insani Malang sejumlah 43 responden yang memiliki pola bermain gadget dengan total skor $\geq 14$ sebanyak 27 responden (62,8\%), yang memiliki total skor 10-13 sebanyak 13 responden $(30,2 \%)$ dan yang memiliki total skor $\leq 9$ sebanyak 3 responden (7\%). 
Tabel 4 Distribusi Frekuensi Responden Berdasarkan Kemampuan Kognitif Pada Anak Usia Prasekolah

\begin{tabular}{ccc}
\hline Kemampuan Kognitif & Frekuensi & Presentase \\
\hline Baik (Skor $\geq 48$ ) & 35 & $81,4 \%$ \\
Sedang (Skor 34-47) & 8 & $18,6 \%$ \\
Kurang (Skor $\leq 33$ ) & 0 & $0 \%$ \\
\hline Total & 43 & $100 \%$ \\
\hline
\end{tabular}

Sesuai dengan tabel diatas, data tersebut dapat dinyatakan bahwa anak usia Preschool (5-6 Tahun) di TKAisyiyah Bustanul Athfal 33 Cita Insani Malang sejumlah 43 responden yang memiliki kemampuan kognitif dengan total skor $\geq 48$ sebanyak 35 responden $(81,4 \%)$, yang memiliki total skor $34-47$ sebanyak 8 responden $(18,6 \%)$ dan tidak ada yang memiliki skor $\leq 33$.

\section{Tabel 5 Distribusi Frekuensi Responden Berdasarkan Kemampuan Berpikir Kreatif}

\begin{tabular}{|c|c|c|c|c|}
\hline Kemampuan Berpikir Kreatif & Frekuensi & \multicolumn{3}{|c|}{ Presentase } \\
\hline Tinggi (Skor $>75 \%)$ & 22 & \multicolumn{3}{|c|}{$51,2 \%$} \\
\hline Sedang (Skor 51\%-74\%) & 16 & \multicolumn{3}{|c|}{$37,2 \%$} \\
\hline Rendah (Skor $\leq 50 \%$ ) & 5 & \multicolumn{3}{|c|}{$11,6 \%$} \\
\hline Total & 43 & \multicolumn{3}{|c|}{$100 \%$} \\
\hline \multicolumn{2}{|c|}{$\begin{array}{l}\text { Sesuai dengan tabel diatas, dapat } \\
\text { disimpulkan bahwa anak usia } \\
\text { Preschool (5-6 Tahun) di TK-Aisyiyah } \\
\text { Bustanul Athfal } 33 \text { Cita Insani Malang } \\
\text { sejumlah } 43 \text { responden yang memiliki } \\
\text { kemampuan berpikir kreatif dengan }\end{array}$} & \multicolumn{3}{|c|}{$\begin{array}{l}\text { total skor }>75 \% \text { sebanyak } 22 \\
\text { responden }(51,2 \%) \text {, yang memiliki total } \\
\text { skor } 51 \%-74 \% \text { sebanyak } 16 \text { responden } \\
\text { ( } 37,2 \%) \text { dan yang memiliki skor } \leq 50 \% \\
\text { sebanyak } 5 \text { responden }(11,6 \%) \text {. }\end{array}$} \\
\hline \multicolumn{5}{|c|}{$\begin{array}{c}\text { Tabel } 6 \text { Gambaran Hubungan Pola Bermain Gadget dengan Kemampuan } \\
\text { Kognitif }\end{array}$} \\
\hline \multirow[t]{2}{*}{ Pola Bermain Gadget } & \multicolumn{3}{|c|}{ Kemampuan Kognitif } & \multirow[t]{2}{*}{ Total } \\
\hline & $\begin{array}{c}\text { Baik } \\
\text { (Skor } \geq 48)\end{array}$ & $\begin{array}{c}\text { Sedang } \\
\text { (Skor 34-47) }\end{array}$ & $\begin{array}{c}\text { Kurang } \\
(\text { Skor } \leq 33)\end{array}$ & \\
\hline \multirow[t]{2}{*}{ Sesuai (Skor $\geq 14$ ) } & 23 & 4 & 0 & 27 \\
\hline & 85 & 15 & 0 & 100 \\
\hline \multirow[t]{2}{*}{ Cukup Sesuai (Skor 10-13) } & 10 & 3 & 0 & 13 \\
\hline & 77 & 23 & 0 & 100 \\
\hline \multirow[t]{2}{*}{ Kurang Sesuai (Skor $\leq 9$ ) } & 2 & 1 & 0 & 3 \\
\hline & 67 & 33 & 0 & 100 \\
\hline \multirow[t]{2}{*}{ Total } & 35 & 8 & 0 & 43 \\
\hline & 81 & 19 & 0 & 100 \\
\hline
\end{tabular}

Pada tabel 6 diatas dapat dilihat bahwa dari 43 responden terbagi menjadi 9 kelompok. Responden yang memiliki tingkat kemampuan kognitif baik (skor $\geq 48$ ) dengan pola bermain gadget sesuai (skor $\geq 14$ ) sebanyak 23 responden (54\%), pola bermain gadget cukup sesuai (skor 10-13) sebanyak 10 responden $(23 \%)$ dan pola bermain 
gadgetkurang sesuai (skor $\leq 9)$ sebanyak 2 responden $(5 \%)$.

Responden yang memiliki tingkat kemampuan kognitif sedang (skor 34-47) dengan pola bermain gadget sesuai (skor $\geq 14$ ) sebanyak 4 responden $(9 \%)$, pola bermain gadget cukup sesuai (skor 10-13) sebanyak 3 responden (7\%) dan pola bermain gadgetkurang sesuai (skor $\leq 9)$ sebanyak 1 responden $(2 \%)$.
Responden yang memiliki tingkat kemampuan kognitif kurang (skor s33) dengan pola bermain gadget sesuai $($ skor $\geq 14)$ sebanyak 0 responden $(0 \%)$, pola bermain gadget cukup sesuai (skor 10-13) sebanyak 0 responden $(0 \%)$ dan pola bermain gadgetkurang sesuai (skor $\leq 9)$ sebanyak 0 responden $(0 \%)$.

\section{Tabel 7 Gambaran Hubungan Pola Bermain Gadget dengan Kemampuan} Berpikir Kreatif.

\begin{tabular}{cccccc}
\hline Pola Bermain Gadget & \multicolumn{4}{c}{ Kemampuan Berpikir Kreatif } & Total \\
\cline { 2 - 5 } & & $\begin{array}{c}\text { Tinggi } \\
(\text { Skor }\end{array}$ & $\begin{array}{c}\text { Sedang } \\
(\text { Skor 51\%- }\end{array}$ & $\begin{array}{c}\text { Rendah } \\
\text { (Skor }\end{array}$ & \\
& & $>75 \%)$ & $74 \%)$ & $\leq 50 \%)$ & \\
\hline Sesuai (Skor $\geq 14)$ & $f$ & 18 & 8 & 1 & 27 \\
& $\%$ & 42 & 19 & 2 & 100 \\
\hline Cukup Sesuai (Skor 10-13) & $f$ & 4 & 7 & 2 & 13 \\
& $\%$ & 9 & 16 & 5 & 100 \\
\hline Kurang Sesuai (Skor $\leq 9)$ & $f$ & 0 & 1 & 2 & 3 \\
& $\%$ & 0 & 2 & 5 & 100 \\
\hline Total & $f$ & $\mathbf{2 2}$ & $\mathbf{1 6}$ & $\mathbf{5}$ & $\mathbf{4 3}$ \\
& $\%$ & $\mathbf{5 1}$ & $\mathbf{3 7}$ & $\mathbf{1 2}$ & $\mathbf{1 0 0}$ \\
\hline
\end{tabular}

Pada tabel 7 diatas dapat dilihat bahwa dari 43 responden terbagi menjadi 9 golongan. Responden yang mempunyai kemampuan berpikir kreatif tinggi (skor $>75 \%$ ) dengan pola bermain gadget sesuai (skor $\geq 14$ ) sebanyak 18 responden (42\%), pola bermain gadget cukup sesuai (skor 10-13) sebanyak 4 responden $(9 \%)$ dan pola bermain gadgetkurang sesuai (skor $\leq 9)$ sebanyak 0 responden (0\%).

Responden yang memiliki tingkat kemampuan berpikir kreatif sedang (skor 51\%-74\%) dengan pola bermain gadget sesuai (skor
214) sebanyak 8 responden (19\%), pola bermain gadget cukup sesuai (skor 10-13) sebanyak 7 responden $(16 \%)$ dan pola bermain gadget kurang sesuai (skor $\leq 9)$ sebanyak 1 responden (2\%).

Responden yang mempunyai kemampuan berpikir kreatif rendah (skor $\leq 50 \%$ ) dengan pola bermain gadget sesuai $($ skor $\geq 14$ ) sebanyak 1 responden (2\%), pola bermain gadget cukup sesuai (skor 10-13) sebanyak 2 responden (5\%) dan pola bermain gadgetkurang sesuai (skor $\leq 9)$ sebanyak 2 responden (5\%). 


\section{Analisis Bivariat}

Tabel 8 Analisis Data Hubungan Pola Bermain Gadget dengan Kemampuan Kognitif menggunakan Uji Rank Spearman

\begin{tabular}{ccc}
\hline Variabel & Korelasi Spearman & Sig. \\
\hline $\begin{array}{c}\text { Pola Bermain Gadget dengan } \\
\text { Kemampuan Kognitif }\end{array}$ & 0,169 & 0,279 \\
\hline
\end{tabular}

Pada hasil uji dapat dilihat bahwa, diketahui nilai signifikansi sebesar 0,279. Karena nilai signifikansi 0,279 > lebih besar dari
0,05, maka artinya tidak ada hubungan yang signifikan antara variabel pola bermain gadget dengan kemampuan kognitif.

Tabel 9 Analisis Data Hubungan Pola Bermain Gadget dengan Kemampuan Berpikir Kreatif menggunakan Uji Rank Spearman

\begin{tabular}{|c|c|c|}
\hline Variabel & $\begin{array}{l}\text { Korelasi } \\
\text { Spearmam }\end{array}$ & Sig. \\
\hline $\begin{array}{c}\text { Pola Bermain Gadget dengan Kemampuan } \\
\text { Berpikir Kreatif }\end{array}$ & 0,633 & 0,000 \\
\hline
\end{tabular}

Pada hasil uji dapat dilihat bahwa, diketahui nilai signifikansi sebesar 0,000 . Karena nilai signifikansi $0,000<$ lebih kecil dari 0,05 , maka artinya ada hubungan yang signifikan (berarti) antara variabel pola bermain gadget dengan kemampuan berpikir kreatif. Dari data output SPSS diperoleh angka koefisien korelasi sebesar 0,633. Yang berarti, tingkat kekuatan korelasi hubungan antara variabel pola bermain gadget dengan kemampuan berpikir kreatif sebesar 0,633 yang berarti kuat.Selain itu, koefisien korelasi bernilai positif, sehingga hubungan kedua variabel tersebut bersifat searah, yang berarti apabila pola bermain gadgetpada anak usia prasekolah baik, maka kemampuan berpikir kreatif anak juga akan meningkat.

\section{PEMBAHASAN}

Penelitian ini di lakukan di TKAisyiyah Bustanul Athfal 33 Cita Insani Malang yang berada di Perumahan Griya Shanta blok K no 331. wilayah Kecamatan Lowokwaru Kota Malang, Jawa Timur. Penelitian ini memperoleh sampel sebanyak 43 responden sesuai kriteria yang merukapan anak usia prasekolah (5-6 tahun).

Berdasarkan hasil penelitian terhadap 43 anak di TK-Aisyiyah Bustanul Athfal 33 Cita Insani Malang menunjukan bahwa kemampuan kognitif anak yaitu yang telah di jelaskan pada tabel 5.2.2. Anak yang memiliki kemampuan kognitif baik sebanyak 35 responden $(81,4 \%)$, kemampuan kognitif sedang sebanyak 8 responden $(18,6 \%)$ dan kemampuan kognitif kurang sebanyak 0 responden $(0 \%)$.

Menurut penjelasan diatas dapat disimpulkan bahwa sebagian 
besar responden yakni sebanyak 35 responden $(81,4 \%)$ siswa TKAisyiyah Bustanul Athfal 33 Cita Insani Malang (5-6 tahun) memiliki kemampuan kognitif baik. Hal ini didukung dengan pendapat guru kelas yang mengatakan bahwa sebagian besar anak-anak yang berusia 5-6 tahun (kelas b) di TKAisyiyah Bustanul Athfal 33 Cita Insani Malang sudah mampu untuk membaca, menulis maupun membilang angka 1 sampai 10. Kemampuan kognitif anak yang baik tersebut tidak terpengaruh oleh kesesuaian pola anak dalam bermain gadget hal ini ditunjukan dengan hasil analisis yang tidak signifikan pada hubungan pola bermain gadget dengan kemampuan kognitif atau $p>0,05$ sehingga h0 diterima dan ha ditolak. Berdasarkan wawancara dengan guru kelas, setiap harinya anak-anak di TK-Aisyiyah Bustanul Athfal 33 Cita Insani Malang diberikan pelajaran berupa menulis, membaca, menghitung, mengenal warna bentuk maupun ukuran. Hal ini dilakukan sekolah karena untuk mempersiapkan anak didiknya memasuki jenjang pendidikan selanjutnya yakni Sekolah Dasar. Sehingga anak-anak sebagai responden sudah sangat mengerti dan paham pada saat skrining kemampuan kognitif.

Faktor-faktor

yang

mempengaruhi kemampuan kognitif di antaranya adalah faktor genetik, faktor lingkungan (prenatal, intenatal dan pascanatal) faktor lingkungan dapat juga mempengaruhi tumbuh kembang anak seperti faktor biologis (ras, jenis kelamin, umur, gizi, dll), faktor lingkungan fisik (cuaca, musim, sanitasi, keadaan rumah, dll) serta faktor psikososial (stimulasi dan motivasi belajar). ${ }^{4}$

Berdasarkan pada hasil penelitian terhadap 43 anak di TKAisyiyah Bustanul Athfal 33 Cita Insani Malang menunjukan bahwa kemampuan berpikir kreatif anak yaitu yang telah di jelaskan pada tabel 7. Sejumlah 43 responden yang memiliki kemampuan berpikir kreatif dengan total skor $>75 \%$ sebanyak 22 responden $(51,2 \%)$, yang memiliki total skor $51 \%-74 \%$ sebanyak 16 responden (37,2\%) dan yang memiliki skor $\leq 50 \%$ sebanyak 5 responden $(11,6 \%)$.

Menurut penjelasan diatas dapat disimpulkan bahwa sebanyak 22 siswa TK-Aisyiyah Bustanul Athfal 33 Cita Insani Malang mempunyai kemampuan berpikir kreatif baik. Kemampuan berpikir kreatif anak baik tersebut merupakan dampak positif dari pola bermain gadget yang sesuai dengan usia yang seharusnya dan juga disebabkan karena adanya stimulasi otak anak setiap harinya. Hal ini didukung dengan pendapat guru kelas bahwa setiap hari anak diberikan stimulasi kreativitas berupa melukis, menggambar, melengkapi gambar, mengkombinasikan gambar, menyusun puzzle, lego dan lainnya. $\mathrm{Hal}$ ini sesuai dengan penjelasan Harlockyang mengatakan bahwa berpikir kreatif dapat ditingkatkan dari aktifitasseperti melukis, bertukang, menjahit, kolase, bermain playdough, menari, mendengarkan musik, menghubungkan gambar, pola, bentuk, bermain puzzle, mengurutkan objek, memasangkan 
sesuai bentuk, ukuran ataupun warna,komunikasi verbal, mengorganisasikan objek sesuai urutan, pengukuran, memecahkan masalah dan juga klasifikasi. ${ }^{5}$

Dari segi usia, tidak ada pengaruh yang signifikan terhadap kemampuan berpikir kreatif karena responden memiliki rata-rata usia yang hampir sama yaitu 5-6 tahun. Kemudian dari segi kelamin, berdasarkan hasil tes juga tidak terdapat perbedaan yang signifikan terhadap kemampuan berpikir kreatif. Walaupun menurut Hurlock\& Santrock, anak laki-laki menunujukan kemampuan berpikir kreatif yang lebih besar dari pada anak perempuan, terutama setelah berlalunya masa kanak-kanak. ${ }^{5}$

Pembentukan kreatifitas anak saat melakukan tes berpikir kreatif dipengaruhi oleh beberapa faktor yaitu kemampuan kognitif (pendidikan formal dan informal), karakteristik kepribadian, motivasi intrinsik, dan lingkungan sosial (tidak adanya tekanan-tekanan dari lingkungan sosial). ${ }^{6}$ Dalam penelitian ini saat anak melakukan tes berpikir kreatif, anak tidak dalam tekanan sosial dalam bentuk apapun baik dari peneliti maupun dari guru yang mendampingi sehingga anak merasa bebas dalam mengekspresikan kreativitasnya. Faktor lain yang menunjang anak dalam membentuk kreativitasnya adalah kemampuan kognitif dimana anak selama ini telah mendapatkan pembelajaran formal berupa pelajaran seni dari sekolah. Kemudian untuk karakteristik kepribadian dan motivasi intrinsik yang dimiliki oleh anak dalam penelitian ini juga dapat membantu dalam membentuk kreativitas anak malalui berpikir kreatif karena anak bersungguh sungguh dalam memunculkan ide-ide kreativitasnya saat melakukan tes berpikir kreatif, selain itu hal ini juga ditunjang dengan fasilitas gambar-gambar yang ada di dinding sekolah sehingga dapat membantu anak dalam berpikir untuk memunculkan kreativitasnya.

Berdasarkan hasil analisis data untuk mengetahui hubungan antara pola bermain gadget dengan kemampuan kognitif dan berpikir kreatif pada anak usia prasekolah (5-6 tahun) di TK-Aisyiyah Bustanul Athfal 33 Cita Insani Malang yang menggunakan uji statistik nonparametrik, yaitu uji korelasi Rank Spearman. Untuk hasil analisis hubungan antara pola bermain gadget dengan kemampuan kognitif memiliki $p$ value $(0,279)>\alpha \quad 0,05(5 \%)$ yang berarti hasil penelitian tidak signifikan atau tidak berkolerasi. Dari hasil Koefisien korelasi menunjukan nilai $r(0,169)$ dimana nilai $r$ tabel 43 responden adalah $(0,2483)$. Hal ini menunjukan bahwa tidak adanya hubungan antara pola bermain gadget dengan kemampuan kognitif pada anak prasekolah atau tidak signifikan dan memiliki korelasi dengan kategori sangat lemah.

Sedangkan untuk hasil analisis hubungan pola bermain gadget dengan kemampuan berpikir kreatif pada anak usia prasekolah (5-6 tahun) memiliki $p$-value $(0,000)<\alpha$ 0,05 yang berarti hasil penelitian signifikan atau berkolerasi. Dari hasil Koefisien Korelasi menunjukan nilai $r(0,633)$ dimana nilai $r$ tabel 
dengan responden sebnyak 43 orang adalah $(0,2483)$ yang menunjukan bahwa adanya hubungan pola bermain gadget dengan kemampuan berpikir kreatif pada anak prasekolah (5-6 tahun) dengan derajat kekuatan, kuat. Hasil analisis juga menunjukan nilai positif atau searah sehingga semakin sesuai pola bermain gadget pada anak (meliputi durasi, frekuensi, jenis aplikasi, jenis permainan dan dampingan orang tua) maka semakin tinggi pula tingkat berpikir kreatif anak.

Hasil tersebut sesuai dengan teori yang mengatakan bahwa teknologi modern memberi kesempatan pada anak untuk mengembangkan inisiatif kemandirian dan berimajinasi, yang menjadi penguat kreativitas anak. ${ }^{2}$ Selain itu, pada teori lainnya mengungkapkan bahwa anak-anak yang menggunakan gadget khususnya menggunakan stylus tablet, lebih unggul dalam hal menggambar. Stylus lebih menghasilkan garis tebal dan tekstur dalam gambar anak. Hal ini memungkinkan anak-anak untuk lebih ekspresif dalam menciptakan tanda hubung, titik, gumpalandan bintik-bintik, yang dihasilkan dalam gambarnya. ${ }^{7}$

Berpikir kreatif erat kaitannya dengan proses kognitif sehingga pada saat anak bermain gadget sesuai dengan durasi, frekuensi, jenis aplikasi dan permainan yang tepat maka terjadi stimulasi verbal, auditif, visual, taktil yang kemudian akan merangsang saraf anak hingga terjadi aktivasi korteks prefrontal dari otak, dimana korteks prefrontal berfungsi untuk memberi dan menerima informasi dari semua indera, lalu menggabungkan informasi tersebut sehingga berguna untuk membentuk penilaian. ${ }^{8}$ Hal ini dibuktikan pada hasil penelitian bahwa sejumlah 20 anak yang memiliki tingkat kognitif yang baik, tingkat berpikir kreatifnya juga tinggi. Dan pada 4 anak yang memiliki tingkat kognitif yang sedang, tingkat berpikir kreatifnya juga sedang.

\section{KESIMPULAN}

Berdasarkan hasil penelitian dan pembahasan mengenai "Hubungan Pola Bermain Gadget dengan Kemampuan Kognitif dan Berpikir Kreatif Pada Anak Usia Prasekolah (5-6 tahun) di TKAisyiyah Bustanul Athfal 33 Cita Insani Malang". Maka dapat disimpulkan sebagai berikut:

1. Pola bermaingadget anak di TKAisyiyah Bustanul Athfal 33 Cita Insani Malang sebagian besar sesuai dengan usia anak yaitu dengan durasi seminggu sekali, 1 kali dalam sehari, dalam sehari bermain kurang dari 1 jam, jenis aplikasi yang digunakan adalah permainan dan menonton video, jenis games yang digunakan adalahedukasi/pendidikan dan puzzle.

2. Kemampuankognitifanakusia prasekolah (5-6 tahun) di TKAisyiyah Bustanul Athfal 33 Cita Insani Malang baik, yakni terbukti 35 dari 43 anak memiliki skor kemampuan kognitif $\geq 48$.

3. Kemampuanberpikirkreatifanak usia prasekolah (5-6 tahun) di TK-Aisyiyah Bustanul Athfal 33 Cita Insani Malang tinggi, yakni terbukti 22 dari 43 anak memiliki 
skor kemampuan berpikir kreatif $\geq 75 \%$.

4. Tidakterdapathubungan yang signifikan antara pola bermain gadget dengan tingkat kognitif anak. Dan terdapat hubungan yang signifikan antara pola bermain gadget dengan kemampuan berpikir kreatif anak, yaitu semakin sesuai anak bermain gadget maka tingkat kemampuan berpikir kreatifnya akan semakin tinggi.

\section{SARAN}

1. Bagi Penelitian Selanjutnya Peneliti menyarankan untuk penelitian selanjutnya untuk turut melakukan penelitian terkait dengan faktor-faktor yang mempengaruhi perkembangan kognitif dan berpikir kreatif pada anak baik itu yang dapat meningkatkan maupun yang dapat menurunkan kemampuan kognitif dan berpikir kreatif pada anak.

Hasil penelitian ini hanya berlaku pada saat itu karena menggunakan metode cross sectional sehingga disarankan peneliti selanjutnya untuk melakukan eksperimen yang dikontrol variabel kemampuan kognitifnya menggunakan metode lain yang sesuai.

2. Bagi Orang tua

Saran untuk orang tua sebaiknya anak selalu di awasi dan didampingi saat menggunakan gadget sehingga durasi, frekuensi, jenis aplikasi dan jenis permainan dapat sesuai dengan usia anak dan dapat

membantu memaksimalkan perkembangan kognitif dan berpikir kreatif pada anak usia prasekolah.

3. Bagi Sekolah

Manfaat penelitian ini bagi sekolah diharapkan untuk kedepannya terkait dengan kemampuan kognitif dan berpikir kreatif anak lebih diperhatikan lagi dengan cara memberikan stimulasi-stimulasi kemampuan kognitif dan berpikir kreatif anak yang tepat sehingga dapat berkembang dengan baik serta di harapkan dapat mengawasi pola bermain gadget pada anak di sekolah

\section{DAFTAR PUSTAKA}

1. Wijanarko, J dan Ester, S. 2016. Ayah Baik- Ibu Baik, Perinting Era Digital (Pengaruh Gadget dan Perilaku Terhadap Kemampuan Anak). Jakarta: Bumi Bintaro Permai.

2. Stosic, L., dan Irena. 2014. Impact Of Computers On The Creativity of Children. International Journal of Cognitive Reasearch in Science, Engineering and Education Vol. 2, No. 2, 2014 Sitompul, R. 2003. Memacu Potensi Kreatif melalui pembelajaran. Pelangi Pendidikan, 10 (3): 93-97.

3. Supardi, U.S. 2015. Peran Berpikir Kreatif dalam Pembelajaran Matematika. Jurnal Formatif 2 (3): 248-262. ISSN: 2088-35IX.

4. Soetjiningsih. 2013. Tumbuh Kembang Anak. Jakarta: EGC.

5. Santrock, J. 2007. Perkembangan Anak. Jilid 1 Edisi kesebelas. Jakarta : PT. Erlangga. 
6. Nur'aeni. 2008. Ada Apa through their interactions with dengan Kreativitas?.Islamadina, Vol. VII, No. 3, September 2008: 74-84, ISSN : 1412-4777: Fakultas Psikologi Universitas Muhammadiyah Purwokerto.

7. Matthews J., \&Seow, P. 2007. Electronic paint: Understanding Children's representation digital paint. Journal of Art Design, 26(3), 251-263.

8. Fuster, J.M. 2008. Cognitive Functions of The Prefrontal Cortex. In: Stuss DT, Knight RT, eds Principles of Frontal Lobe Function. Second Edi. USA: Oxford. 